\title{
Studies on the Growth and Yield of Prostrate Groundnut Variety (Arachis hypogaea L.) as Affected by Oil Palm Bunch Ash in Umudike Southeastern Nigeria
}

\author{
Akpan A. U. ${ }^{\rtimes(i D)}$ \\ Eka, M. J. ${ }^{2}$ \\ Department of Agronomy, Michael Okpara University of Agriculture, Umudike, Southeastern, Nigeria \\ Email:annahudo@yahoo.com
}

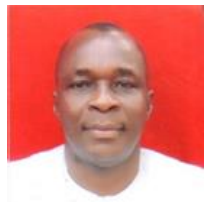

( Corresponding author)

\section{Abstract}

An experiment on studies on the growth and yield of prostrate groundnut variety (Arachis hypogaea L.), as affected by oil palm bunch ash in Umudike, Southeastern, Nigeria, was conducted at the eastern farm of Michael Okpara University of Agriculture, Umudike, Abia State. The research was laid out in a randomized complete block design (RCBD), with three replications. The treatments comprised the oil palm bunch ash levels of $0,4,6$ and 8 tha $^{-1}$. Result, showed that number of leaves per plant increased at 4 and 8 weeks after planting (WAP), and declined at $12 \mathrm{WAP}$ due to senescence. Number of branches per plant increased at 4, 8 and $12 \mathrm{WAP}$, while shoot dry weight increased at 4 and $8 \mathrm{WAP}$, and declined at 12 due to senescence. Dry matter content was higher at 4 WAP, but dropped at 8 and 12 WAP, due to the translocation of photoassimilates (biomass) as the crop developed in age. 8 tha $^{-1}$ of oil palm bunch ash produced highest growth parameters compared with the control $\left(0\right.$ tha $\left.^{-1}\right)$. Improved number of seeds per pod (18.27 pods); number of seeds per plant (27.7 seeds); weight of pods per plant (20.89g); weight of seeds per plant (15.27g), 100-seeds weight (57.8g); harvest index (0.17); shelling percentage (74.2\%); pod yield (5.22 tha-1) and seed yield (3.82 tha ${ }^{-1}$ ) were obtained at 8 tha $^{-1}$, although performances were statistically similar. Consequently, 8 tha $^{-1}$ of oil palm bunch ash is recommended for the cultivation of groundnut in Umudike, Southeastern, Nigeria.

Keywords: Growth, Yield, Groundnut, Oil palm bunch ash.

Citation | Akpan A. U.; Eka, M. J. (2019). Studies on the Growth and Yield of Prostrate Groundnut Variety (Arachis hypogaea L.) as Affected by Oil Palm Bunch Ash in Umudike Southeastern Nigeria. Agriculture and Food Sciences Research, 6(2): 198-202. History:

Received: 8 April 2019

Revised: 17 May 2019

Accepted: 28 June 2019

Published: 22 August 2019

Licensed: This work is licensed under a Creative Commons

Attribution 3.0 License $(\mathrm{coc}) \mathbf{E Y}$

Publisher: Asian Online Journal Publishing Group
Acknowledgement: The authors appreciate all the workers of the University farms for their unalloyed supports, throughout the duration that the research lasted.

Funding: This study received no specific financial support

Competing Interests: The authors declare that they have no conflict of interests.

Transparency: The authors confirm that the manuscript is an honest, accurate, and transparent account of the study was reported; that no vital features of the study have been omitted; and that any discrepancies from the study as planned have been explained.

Ethical: This study follows all ethical practices during writing.

\section{Contents}

1. Introduction 


\section{Contribution of this paper to the literature}

This research has further revealed that oil palm bunch ash is veritable organic manure, with dual purposes of ameliorating a declining soil fertility and acidity. Equally, groundnut cultivation in Southeastern Nigeria can be carried out with the application of organic manures like the oil palm bunch ash.

\section{Introduction}

Groundnut (Arachis hypogaea L.), is a major crop grown in the arid and semi-arid zones of Nigeria. It is either grown for its nut, oil or its vegetative residue (haulms) [1]. Groundnut, also known as peanut, is an important food and cash crop grown across West Africa. The crop is cultivated mainly by small-household and resources poor farmers. It is a self-pollinated, tropical annual legume [2]. It is an important crop in Nigeria as it occupied 13-27\% of the total area in some state of the country [3].

Groundnut is a legume that ranks $4^{\text {th }}$ among the oil seed crops and $13^{\text {th }}$ among the food crops of the world. It provides high quality edible oil (48-50\%), used in cooking, margarine, salads, easily digestible protein (26 to $28 \%$ ), and about half of the 13 essential vitamins and more than a $2 / 3^{\text {rd }}$ of the 20 essential minerals necessary for normal human growth and maintenance. It produces high quality fodder for livestock [4]. Being a legume, it synthesizes atmospheric nitrogen into root nodule with a symbiotic association of Rhizobium and thereby improves soil for fertility [5].

The main factors responsible for low yield in groundnut are the inadequate use of nutrients as well as nutrient deficiencies. Organic manure such as oil palm bunch ash is one of the major sources of essential plant nutrients gaining importance in groundnut production. Oil palm bunch ash is an organic residue derived from the incineration of oil palm bunch refuse after fruit extraction.

According to Akpan [6] the scarcity and high cost of inorganic fertilizer led to intensification of research into low-cost, internally sourced, cheap, affordable and adoptable organic materials that could serve as liming agents and fertilizers. Akpan [7]; Akpan and Mbah [8] and Akata [9] studied effect of liming materials such as plant derived ash and saw dust on cucumber and cassava yields, the materials were found to increase soil $\mathrm{PH}^{\mathrm{H}}$ and crop yield. Ntare, et al. [10]; Obi [11] and Moyin-Jesu [12] found out that plant derived ash including those of wood and cocoa pod, increased soil chemical properties, $\mathrm{PH}$ and yield of vegetables, cassava and maize. Mbah and Akpan [13] reported that ash is an effective fertilizer and liming material for improving soil fertility, while Ikeh, et al. [4] stressed that combined application of oil palm bunch ash and poultry manure at 2.5 tha $^{-1}$ rate each resulted to high tuber yield of water yam. Effiong, et al. [14] found that oil palm bunch ash and poultry manure treatments increased the soil $\mathrm{PH}$, O.M, N, P, K, Ca, Mg by 6\%, 13\%, 19\%, 28\%, 32\%, 33\% and 21\% respectively. Akpan [6] reported that oil palm bunch ash increased soil nutrient contents and uptake of nutrients by maize and these effects led to significant increase in maize yield.

Essien [15] attributed the superiority of organic manure to the slow release of balanced nutrient during decomposition. This makes organic waste of greater residual beneficial effects distributed over longer period than inorganic fertilizers Asiegbu [16]. Gomez and Gomez [17] reported high growth and yield of groundnuts at 4 tha${ }^{1}$ of oil palm bunch ash manure. The objective of this research therefore, is to evaluate the growth and yield of prostrate groundnut (Arachis hypogaea L.) as affected by oil palm bunch ash in Umudike, Southeastern, Nigeria.

\section{Materials and Methods}

The experiment was conducted at the Teaching and Research Farm of Michael Okpara University of Agriculture, Umudike, during 2018 cropping season. Umudike is located on latitude $05^{\circ} 29^{\prime} \mathrm{N}$ and longitude $07^{\circ} 33^{\prime} \mathrm{E}$, on the elevation of $122.0 \mathrm{~m}$ above sea level. It has a maximum and minimum temperature of $33^{\circ} \mathrm{C}$ and $24^{\circ} \mathrm{C}$, annual rainfall of $21,690.8 \mathrm{~mm}$ and relative humidity range of $50 \%-95 \%$ respectively. Rainfall pattern is however bimodal, with rainfall commencing from March to October, with a short dry spell in August, NRCRI [18].

The experiment was laid out in a randomized complete block design. (RCBD) with three replications. The treatments comprised the oil palm bunch ash levels of $0,4,6$ and 8 tha $^{-1}$. The prostrate groundnut variety (G153), used in this study was obtained from the Institute for Agricultural Research (IAR), Ahmadu Bello University, Zaria, Kaduna State. The experimental layout was $24.5 \times 7.4 \mathrm{~m}\left(181.3 \mathrm{~m}^{2}\right)$, with each plot measuring $1.8 \mathrm{~m} \times 2.0 \mathrm{~m} ; 0.5 \mathrm{~m}$ spacing between plot and $1 \mathrm{~m}$ spacing between replicates. Planting spacing was $50 \mathrm{~cm} \times 30 \mathrm{~cm}$, resulting in a plant population of 66,667 plants ha' ${ }^{-1}$.

Before planting, the site was mechanically ploughed and subsequently harrowed. Planting was done in May $5^{\text {th }}$ on bed. Two to three seeds were planted per hole, while thinning to one plant per stand was conducted at 14 days after planting (DAP). Oil palm bunch ash manure at the rates of 0,2,4, 6 and 8 tha $^{-1}$, was applied by ring method after thinning at 14 DAP. Empty oil palm bunches were obtained from a local oil mill. They were dried properly before incineration to obtain the ash. The research plots were weeded once at $3 \mathrm{WAP}$, with hoe, while insect pests were controlled by the use of cypermethrin-10 EC. at $2.5 \mathrm{ml}$ litre-1 of water using a knapsack sprayer once at 4 WAP [19]. Harvesting was conducted at the end of August, precisely 4 months after planting.

Data collection on vegetative parameters such as: number of leaves per plant, number of branches per plant, shoot dry weight per plant and dry matter content were conducted at 4, 8 and 12 WAP, while reproductive parameters including: number of pods per plant, number of seeds per plant, weight of pods per plant, weight seeds per plant, 100 - seed weight, harvest index, shelling percentage, pod yield and seed yield $\left(\right.$ tha $\left.^{-1}\right)$, were obtained after harvest at maturity.

Before the commencement of the research, composite soil samples were randomly collected at the depth 0-20cm for both physical and chemical analyses. Oil palm bunch ash manure was equally analyzed, while meteorological data bordering on rainfall $(\mathrm{mm})$, relative humidity $(\%)$ and temperature $\left({ }^{\circ} \mathrm{C}\right)$ were obtained from the meteorological unit of National Root Crops Research Institute (NRCRI), Umudike. Both, vegetative and reproductive parameters were subjected to analysis of variance (ANOVA) method [20] while Fisher's Least Significant Difference (F-LSD) at $5 \%$ probability level was adopted to separate means. 


\section{Results and Discussions}

\subsection{Meteorological Properties of the Research Site}

The meteorological properties of the research site Table 1 revealed that monthly rainfall increased from the month of April, (337.5mm) and dropped in the month of November (45mm) preparatory to the commencement of dry season. Both minimum and maximum temperatures were almost stable throughout the year, although with insignificant fluctuations. Relative humidity on the other hand increased from March (80\%), with obvious drop in November due to the beginning of dry season Table 1 . The fluctuation in relative humidity was tandem with that of monthly rainfall. The rainfall situation was in line with the recommendation of Ibia and Udo [21]; Chude, et al. [22] for groundnut cultivation in southeastern Nigeria.

\begin{tabular}{c|c|c|c|c|c|c|c|c|c|c|c|c}
\multicolumn{10}{c}{ Table-1. Meteorological properties of the research site during 2018 cropping season. } \\
\hline Months & Jan. & Feb. & Mar. & April & May & June & July & Aug. & Sept. & Oct. & Nov. & Dec. \\
\hline Rainfall $(\mathrm{mm})$ & $\mathrm{O}$ & 80.1 & 9.6 & 337.5 & 246.6 & 326.6 & 237.0 & 173.3 & 334.7 & 273.4 & 45.0 & 7.3 \\
\hline Tempts. ${ }^{\circ}$ C Min. & 22.6 & 23.8 & 24.6 & 24.7 & 24.9 & 23.1 & 24.1 & 24.4 & 23.3 & 23.7 & 23.9 & 24.1 \\
\hline Max & 34.1 & 34.5 & 34.4 & 32.5 & 32.6 & 30.9 & 29.6 & 30.4 & 30.1 & 30.8 & 32.3 & 32.1 \\
\hline R/humility (\%) & 53 & 77 & 80 & 76 & 81 & 80 & 86 & 87 & 85 & 83 & 80 & 71 \\
\hline
\end{tabular}

\subsection{Physico-Chemical Properties of the Research Site}

The physico-chemical properties of the research site Table 2 showed that the soil was sandy loam in texture, while the sand fraction of $(67.2 \%)$ was capable of sustaining the growth of groundnut. The $\mathrm{PH}^{\mathrm{H}}$ of 4.2 , showed that the site was strongly acidic, and not in conformity with the $\mathrm{P}^{\mathrm{H}}$ of 5.5 to 6.5 recommendation by Ibia and Udo [21] and Chude, et al. [22]. Organic matter $(0.87 \%)$; organic carbon $(0.5 \%)$ and potassium $\left(0.079 \mathrm{cmokg}^{-1}\right)$ were very low, while nitrogen $(0.182 \%)$ and phosphorus $\left(67.8 \mathrm{cmokg}^{-1}\right)$ were moderate and high respectively. The site therefore, requires liming or addition of plant ash for the remediation of its acidic status.

The properties of oil palm bunch ash showed that the acidity level was low due to the high $\mathrm{P}^{\mathrm{H}}$ of 10.8 . It is very rich in almost all the analyzed parameters Table 2 . The rich status of oil palm bunch ash conforms with the reports of varying researchers such as: Ntare, et al. [10]; Effiong, et al. [14]; Akpan [6] and Ikeh, et al. [4]. Plant ash including oil palm bunch ash are veritable liming and fertilizer materials.

\begin{tabular}{|c|c|c|c|c|}
\hline \multicolumn{3}{|c|}{ Soil physical properties } & \multicolumn{2}{|c|}{ Oil palm bunch ash properties } \\
\hline Sand (\%) & - & 67.2 & & - \\
\hline Silt (\%) & - & 12.8 & & - \\
\hline Clay $(\%)$ & - & 20 & & - \\
\hline Textural class & - & sandy loam & & \\
\hline \multicolumn{5}{|l|}{ Soil chemical properties } \\
\hline $\mathrm{PH}^{\mathrm{H}}\left(\mathrm{H}_{2} \mathrm{O}\right)$ & - & 4.2 & - & 10.8 \\
\hline Organic matter (\%) & - & 0.87 & - & 8.02 \\
\hline Organic carbon (\%) & - & 0.5 & - & 4.65 \\
\hline Total nitrogen (\%) & - & 0.182 & - & 0.28 \\
\hline Available p $\left(\mathrm{mgkg}^{-1}\right)$ & - & 67.8 & - & 8.20 \\
\hline Calcium $\left(\mathrm{cmolkg}^{-1}\right)$ & - & 2.8 & - & 3.40 \\
\hline Potassium $\left(\mathrm{cmolkg}^{-1}\right)$ & - & 0.079 & - & 11.50 \\
\hline Magnesium (comolkg $\left.{ }^{-1}\right)$ & - & 1.6 & - & 0.48 \\
\hline Sodium & - & 0.185 & - & 0.87 \\
\hline
\end{tabular}

Source: Field data for soil and oil palm bunch ash samples.

\subsection{Growth of Groundnut as Affected by Oil Palm Bunch Ash}

The evaluated growth attributes showed that number of leaves per plant Table 3 for all treatment increased at 4 and 8 WAP, with a decline at 12 WAP due to senescence. Higher number of leaves per plant was recorded at 8 WAP for the treatments, while 8 tha $^{-1}$ of oil palm bunch ash produced highest number of leaves per plant of 73.7 (4WAP); 156.2 (8 WAP) and 146.0 (12WAP), compared with the control. Number of branches per plant increased at 4, 8 and 12 WAP, with 8 tha $^{-1}$ of oil palm bunch ash producing highest number of braches per plant of 6.85 , (4WAP); 7.58 (8 WAP) and 8.83 (12 WAP) compared with 0 tha $^{-1}$ (control), although performances were statistically similar.

Shoot dry weight Table 3 also increased at 4, 8, and dropped at 12 WAP due to the process of senescence, while 8 WAP produced higher short dry weight for all treatments. $8 \mathrm{tha}^{-1}$ of oil palm bunch ash gave higher shoot dry weight of $21.3 \%$ (4WAP): $69.2 \%$ (8WAP) and $45.8 \%$ (12WAP), compared with the control.

Dry matter contents Table 3 for all treatments was high at 4 WAP, with a decline at both 8 and 12 WAP due to probably to the translocation of phyto-assimilate to sinks as the crop increased in age. 8 tha $^{-1}$ of oil palm bunch ash produced highest dry matter content of $23.3 \%$ (4 WAP); 19.6 (8WAP) and 21.5 (WAP), compared with the control which produced the least values, although performances were statistically similar Table 3.

Both number of leaves per plant and number of branches per plant were significantly $(\mathrm{p}<0.05)$ affected at $12 \mathrm{WAP}$ and 4WAP respectively, while shoot dry weight and dry matter contents were not significantly $(\mathrm{P}>0.05)$ affected at 4, 8 and 12WAP. The increase in number of leaves per plant at 4 and 8 WAP and a decline at 12 WAP, was earlier reported by Akpan [6]; Akpan [7] and Akpan and Mbah [8]. Uko, et al. [2]; Awodun, et al. [20] and Akata [9] all reported higher growth attributes at highest rates of oil palm bunch ash fertilizer, during their respective researches. 


\begin{tabular}{|c|c|c|c|c|c|c|c|c|c|c|c|c|}
\hline \multirow[t]{2}{*}{ Treatments } & \multicolumn{3}{|c|}{ No. of leaves per plant } & \multicolumn{3}{|c|}{$\begin{array}{l}\text { No. of branches per } \\
\text { plant }\end{array}$} & \multicolumn{3}{|c|}{$\begin{array}{c}\text { Shoot dry weight per } \\
\text { plant (\%) }\end{array}$} & \multicolumn{3}{|c|}{$\begin{array}{c}\text { Dry matter content } \\
(\%)\end{array}$} \\
\hline & 4WAP & 8WAP & 12WAP & 4WAP & 8WAP & $12 \mathrm{WAP}$ & 4WAP & $8 \mathrm{WAP}$ & 12WAP & 4WAP & 8WAP & $12 \mathrm{WAP}$ \\
\hline Otha $^{-1}$ & 52.0 & 123.3 & 65.5 & 5.50 & 6.67 & 7.63 & 14.4 & 40.7 & 37.7 & 19.7 & 19.0 & 22.3 \\
\hline 4tha ${ }^{-1}$ & 58.5 & 124.1 & 96.3 & 5.50 & 7.27 & 8.00 & 15.4 & 50.9 & 44.0 & 25.3 & 17.2 & 19.3 \\
\hline 6 tha $^{-1}$ & 58.8 & 134.1 & 126.7 & 5.53 & 7.42 & 8.13 & 17.8 & 54.9 & 45.6 & 19.6 & 18.9 & 21.5 \\
\hline 8 tha $^{-1}$ & 73.7 & 156.2 & 146.0 & 6.85 & 7.58 & 8.83 & 21.3 & 69.2 & 45.8 & 28.7 & 23.3 & 22.8 \\
\hline Means & 60.7 & 132.6 & 110.0 & 5.84 & 7.23 & 8.15 & 17.2 & 53.2 & 44.0 & 23.3 & 19.6 & 21.5 \\
\hline L SD (0.05) & $\mathrm{Ns}$ & $\mathrm{Ns}$ & 57.9 & 1.05 & $\mathrm{Ns}$ & $\mathrm{Ns}$ & $\mathrm{Ns}$ & $\mathrm{Ns}$ & $\mathrm{Ns}$ & $\mathrm{Ns}$ & $\mathrm{Ns}$ & $\mathrm{Ns}$ \\
\hline
\end{tabular}

Source: Field data for vegetative parameters.

\subsection{Yield of Prostrate Groundnut as Affected by Oil Palm Bunch Ash Fertilizer}

All the evaluated yield parameters Table 4 including number of pods per plant, number of seeds per plant, weight of pods per plant, weight of seeps per plant, 100-seed weight, harvest index, shelling percentage (\%), pod yield $\left(\right.$ tha $\left.^{-1}\right)$ and seed yield $\left(\right.$ tha $\left.^{-1}\right)$, all improved with increased levels of oil palm bunch ash, although performances were statistically similar. 8 tha $^{-1}$ of oil palm bunch ash produced highest number of pods per plant (18.27 pods); number of seeds per plant (27.7 seeds); heavier pods (20.89g), heavier seeds (15.27g); 100-seed weight (57.8g); harvest index (0.17); shelling percentage (74.2\%); pod yield $\left(5.22\right.$ tha $\left.^{-1}\right)$ and seed $\left(3.82\right.$ tha $\left.^{-1}\right)$ compared with otha ${ }^{-1}$ (control) with lesser values. The evaluated yield parameters were however not significantly $(\mathrm{p}>0.05)$ affected by the treatments, suggesting that their performances were generally statistically similar. This suggests that the acidic status of the sites must have locked-up the release of macro-nutrients to the plant.

Various researchers, including Uko, et al. [2]; Awodun, et al. [20] and Akata [9] all reported improvement in

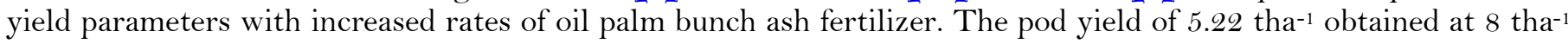
was higher than the pod yield range of 3,000 - 4,500 kgha-1 reported by Olorunju [23] while the seed yield of 3.82 tha ${ }^{-1}$ obtained at 8 tha $^{-1}$ was higher than 2. 58 tha $^{-1}$ reported by Gomez and Gomez [17]. The seed yield of 3.82 tha${ }^{1}$ at 8 tha $^{-1}$ of oil palm bunch ash was however lower than the 4.0 tha $^{-1}$ reported by Uguru [24].

Table-4. Effect of oil palm bunch ash on some selected yield attributes of prostrate groundnut during 2018 cropping season.

\begin{tabular}{|c|c|c|c|c|c|c|c|c|c|}
\hline Treatments & $\begin{array}{c}\text { No. of } \\
\text { pods } \\
\text { per plant }\end{array}$ & $\begin{array}{c}\text { No. of } \\
\text { seeds per } \\
\text { plant }\end{array}$ & $\begin{array}{c}\text { wt. of pods } \\
\text { per plant } \\
(\mathrm{g})\end{array}$ & $\begin{array}{c}\text { wt. of } \\
\text { seeds per } \\
\text { plant }(\mathrm{g})\end{array}$ & $\begin{array}{c}100 \text { seeds } \\
\text { weight } \\
(\mathrm{g})\end{array}$ & $\begin{array}{c}\text { Harvest } \\
\text { index }\end{array}$ & $\begin{array}{c}\text { Shelling } \\
\text { percentage } \\
(\%)\end{array}$ & $\begin{array}{l}\text { Pod } \\
\text { yield } \\
\text { tha }^{-1}\end{array}$ & $\begin{array}{c}\text { Seed } \\
\text { yield } \\
\left(\text { tha }^{-1}\right)\end{array}$ \\
\hline Otha $^{-1}$ & 12.00 & 22.3 & 16.54 & 13.69 & 50.9 & 0.09 & 72.2 & 4.13 & 3.42 \\
\hline 4 tha $^{-1}$ & 12.83 & 23.8 & 18.71 & 13.93 & 51.7 & 0.13 & 73.0 & 4.68 & 3.48 \\
\hline 6 tha $^{-1}$ & 14.75 & 24.2 & 19.58 & 14.35 & 53.1 & 0.15 & 74.2 & 4.90 & 3.59 \\
\hline 8 tha $^{-1}$ & 18.27 & 27.7 & 20.89 & 15.27 & 57.8 & 0.17 & 74.2 & 5.22 & 3.82 \\
\hline Means & 14.46 & 24.5 & 18.93 & 14.31 & 53.4 & 0.13 & 73.4 & 4.73 & 3.58 \\
\hline L SD(0.05) & ns & ns & ns & ns & ns & ns & ns & ns & ns \\
\hline
\end{tabular}

\section{Conclusion}

The research has revealed that the values of both the growth and yield parameters increased with corresponding increases in the rates of oil palm bunch ash, although their performances were generally statistically similar. 8tha- ${ }^{-1}$ of oil palm bunch ash equally produced highest growth and yield attributes, compared with otha $^{-1}$ (control).

In view of the above therefore, 8 tha $^{-1}$ of oil palm bunch ash is hereby recommended for the cultivation of groundnut in Umudike, Southeastern, Nigeria. The application of lime or plant ash for the remediation of the acidic status of the site is strongly recommended. This will ensure the release of nutrients to the crops.

\section{References}

[1] A. A. Makinde, K. O. Oluwasemire, O. A. Akintola, and H. A. Ademiyi, "Seasonal variability and row arrangement effect on the performance of groundnut (Arachis hypogaea L.) and okra (Abelmoschus esculentus) intercrop in a forest-savanna transition zone of Nigeria," Journal of Applied Agricultural Research, vol. 4, pp. 111-120, 2012.

[2] A. E. Uko, E. B. Effa, and A. U. Akpan, "Effect of oil palm bunch ash and poultry manure on the growth and yield of groundnut (Arachis hypogaea L) in an Ultisol of Uyo, Akwa Ibom State, Nigeria," in Proceedings of the 3rd National Annual Conference of Crops Science Society of Nigeria, Held at the University of Nigeria, Nsukka, Between September 27-30, 2016, 2016, pp. 158-163.

[3] A. Akinmutimi and L. Agwu, "Comparative effects of commercial lime (CaCO 3) and ground eggshell on the uptake of calcium and dry matter yield of maize in an ultisol of Southeastern Nigeria," Nigeria Agricultural Journal, vol. 45, pp. 13-20, 2014.

[4] A. Ikeh, N. Ndaeyo, E. Akpan, E. Udoh, and O. Akata, "Evaluation of complementary use of organic manure for sustainable water yam production in Uyo, Southeastern Nigeria," American Journal of Research Communication, vol. 1, pp. 33-48, 2013.

[5] A. O. Ikeh, O. R. Akata, and E. A. Akpan, "Effect of oil palm bunch refuse ash on sustainable production of egusi melon (Colocynthis citrullus) in acid costal plain soil of Uyo Southeastern, Nigeria," in Proceedings of the third National Annual Conference of Crop Science Society of Nigeria. Held at the University of Nigeria, Nsukka, from September 27-30, 2016, 2016, p. 96.

[6] A. U. Akpan, "Effect of planting density and variety on the vegetative growth and fresh pod yield of two vegetable cowpea (Vigna unguiculata (L) WALP) in Southeastern, Nigeria," Journal of Science of Agricultural Food Technology and the Environment, vol. 13, pp. 74-78, 2014.

[7] A. U. Akpan, "Effect of sowing dates on growth and fresh pod yield of three improved cowpea varieties (Vigna unguiculata (L) Walp.) in Umudike, Southeastern Nigeria," Journal of the Science of Agriculture, Food Technology the Environment, vol. 14, pp. 57-62, 2015 .

[8] A. Akpan and E. Mbah, "Growth and yield of vegetable cowpea varieties (Vigna unguiculata (L) Walp) as influenced by potassium fertilizer rates in Umudike, Nigeria," Nigerian Journal of Agriculture, Food and Environment, vol. 12, pp. 12 1-126, 2016.

[9] O. R. Akata, "Effects of fertilization on a Cassava based intercropping system in Uyo. Southeastern, Nigeria," M.Sc Thesis of the Department of Crop Science, University of Uyo, Akwa Ibom State, Nigeria, 2006.

[10] B. R. Ntare, A. T. Diallo, J. Ndjeunga, and F. Waliyar, "Groundnut seed production manual," ed. Niamey, Niger: International Crops Research Institute for the Semi-Arid Tropics, (ICRISAT), 2008, pp. 6-10.

[11] E. M. Obi, "Growing of native vegetable in Nigeria," Food and Agricultural Organization Handbook, vol. 12, pp. 66-69, 2001.

[12] E. Moyin-Jesu, "Determination of soil nutrient levels for maximum yield of okra (Abelmoschus esculentum) using sole and amended plant residues," Pertanika Journal of Tropical Agricultural Science, vol. 31, pp. 233-245, 2008. 
[13] E. U. Mbah and A. U. Akpan, "Effect of organic manure sources on the growth and yield of groundnut in lowland derived savanna of Ishiagu, Ebonyi State, Nigeria," Journal of Agricultural Food and Environment, vol. 13, pp. 233-245, 2017. [14] G. S. Effiong, T. O. Ibia, P. I. Ogban, and N. D. Inyang, "Evaluation of locally- sourced liming material for acid soils of Akwa Ibom
State, Southern Nigeria," American-Eurasian Journal of Agronomy, vol. 2, pp. 144-151, 2009.

[15] I. E. Essien, "Effect of organic fertilizer on soil micro-organism, growth, yield and nutritional contents of cucumber (Cucumis sativum L.) in Uyo, Akwa Ibom State, Nigeria," Unpublished M. Sc Thesis of the Department of Soil Science and Land Resources Management, University of Uyo, 2015.

[16] J. Asiegbu, "Effects of organic matter substrate sources and time of photosynthate-Sink removal on flower and pod production in Okra, Abelmoschus Esculentus (L) Moench," East African Agricultural and Forestry Journal, vol. 52, pp. 293-297, 1987. Available at: https://doi.org/10.1080/00128325.1987.11663530.

[17] K. A. Gomez and A. A. Gomez, Statistical procedure for agricultural research, 2nd ed. New York: John Wiley and Son Inc, 1984.

[18] NRCRI, "National root crops research insitutute," Handbook, vol. 6, pp. 5-7, 2007.

[19] K. Rajgopal, K. Chandran, J. Misra, P. Bhalodia, and R. Mathur, "Evaluation of bold-seeded groundnut accessions for confectionery attributes," International Arachis Newsletter, vol. 20, pp. 18-20, 2000.

[20] M. Awodun, S. Ojeniyi, A. Adeboye, and S. Odedina, "Effect of oil palm bunch refuse ash on soil and plant nutrient composition and yield of maize," American-Eurasian Journal of Sustainable Agriculture, vol. 1, pp. 50-54, 2007.

[21] T. O. Ibia and E. J. Udo, Guide to fertilizer use for crops in Akwa Ibom State, Nigeria (Teaching, Research and Extension Guide): Sibon Books Limited, 2009.

[22] V. O. Chude, W. B. Malgui, I. Y. Amapu, and A. O. Ano, "Manual on soil fertilizer assessment," pp. 34-35, 2004.

[23] P. E. Olorunju, "Evaluation of production, multiplication and distribution system of improved groundnut germplasm in Nigeria," ATCP/RAF/7823(A) Report. Federal Ministry of Agriculture, Abuja, Nigeria2000.

[24] M. I. Uguru, Crop production: Tools, techniques and practices. Nsukka: Ephrata Press, 2011. 